\title{
THE INFLUENCE OF AUXILARY SUPPLEMENTS ADDED IN THE EXTRUSION PROCESS TO REDUCE THE FRICTION OF A POLYMERIC FOIL
}

\author{
Sebastian Białasz' \\ 1 Mechanical Engineering Faculty, Lublin University of Technology, ul. Nadbystrzycka 36, 20-618 Lublin, Poland, \\ e-mail: sebastian.bialasz@pollub.edu.pl
}

Received: 2018.01.02

Accepted: 2018.07.01

Published: 2018.09.01

\begin{abstract}
The publication describes research on supplements that reduce foil friction in the case of sliding contacts. The supplements added to the LD-PE polymer material were based on the following blends: erucic acid amide, behenic acid amide, colloidal silica, potassium soap and talc. The work contains information on the types of processing additives and the resulting changes in properties in the surface layer of the product in the form of foil.
\end{abstract}

Keywords: foil, friction, extrusion

\section{INTRODUCTION}

Foil is a product made of polymer material, characterized by a low thickness, simultaneously retaining large width and length. In order to divide the foil into various groups, it is necessary to introduce various criteria, i.e. the number of layers of the material: single or multilayer, transparency: transparent, translucent and light-impermeable, surface quality: smooth, matt, shiny, embossed and extruded, the content of plasticizer: hard and soft. Due to the fact that products in the form of foil have very good mechanical properties, they are widely used throughout the industry, including: construction, agriculture and horticulture, and above all, in the packaging industry. The foil intended for packaging must additionally meet various criteria, e.g. resistance to fragrance penetration from the packaging into a product, thickness below $52 \mu \mathrm{m}$, weldability in the temperature within $150-190^{\circ} \mathrm{C}$ range and the desired flexibility (elongation not lower than $70 \%$ ) $[1,6$, $7,10,12]$.

Depending on the type of material and supplements, each type of foil is characterized by different properties, but there are common features characterizing all these types including: high tensile strength, resistance to chemical agents and overall transparency (excluding colored foil). Foil can be produced by several methods, depending on the expected properties and form (roll, sleeve). The most common production methods include: extrusion, pouring, calendering and forming on heated rolls.

Foils products manufactured industrially have thickness of $0.03-1 \mathrm{~mm}$, the width of up to $1.5-2 \mathrm{~m}$, and the length (in the form of a ribbon or sleeve) up to several kilometers. Foil products might be subject to various processes to improve their properties, e.g. activation, electrification or metallization. Foil can also be divided according to the content of plasticizer, as shown in Figure 1 $[2,13,18]$.

\section{Surface layer of a polymer foil}

The surface layer of the foil encompasses that part of the material into the product which is characterized by altered physical and chemical properties (Fig. 2) in relation to the properties of the core. The thickness of the surface layer can range from a few nanometers to several hundred micrometres, however, foil is a product with a thickness not exceeding $1 \mathrm{~mm}$, and thus its surface layer cannot be as complex, as in other plastic products. 


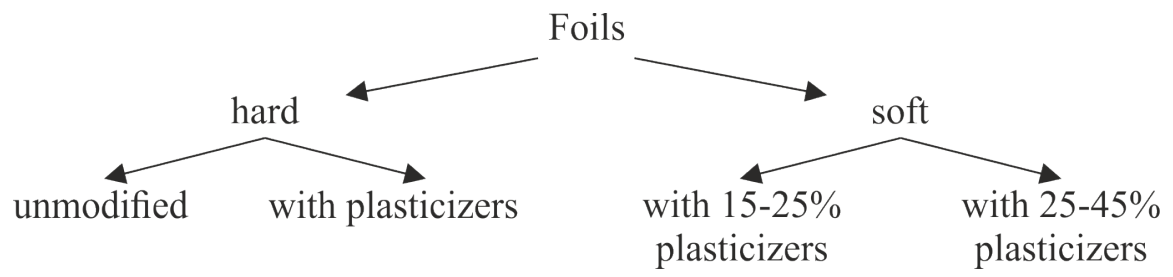

Fig. 1. Diagram showing the classification of foils due to the plasticizer content

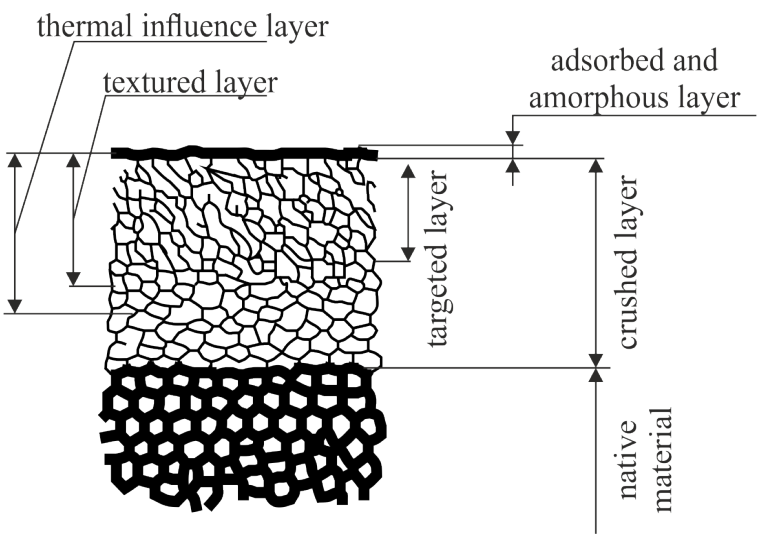

Fig. 2. Diagram of the structure of the surface layer of the foil

While manufacturing foil and also during the subsequent use, the following transformations may take place: mechanical (e.g. when rough surfaces contact), thermal (e.g. during heat generating), physicochemical (e.g. adhesion) and chemical (e.g. oxidation). The structure and properties of the surface layer depend on many factors, i.e.: geometric changes occurring in the processing, additional components (especially fillers) or extortion in the processing (e.g. heat flow intensity) $[5,8]$.

The surface layer is characterized by certain parameters, and some imperfections are possible in its structure (Fig. 3).
The surface layer is important when using plastic objects, including: the top layer has the greatest stresses, both its own and those from external loads; the properties of the surface layer have a very large influence on the processes of friction, lubrication and wear due to the direct contact between the cooperating elements which also affects the appearance and aesthetics of the products.

The surface layer plays a significant role while using plastic objects, including: the surface layer bears the greatest tensions, both internal and those from external loads; the properties of the surface layer have a very large influence on the processes of friction, lubrication and wear due to the direct contact between the cooperating elements, which also affects the appearance and aesthetics of the products.

\section{Friction of foil layers}

The phenomenon of the occurrence of friction force between the foil layers is closely related to the phenomenon of blocking the foil layers. Blocking occurs during winding of the foil round the rolls, in turn the so-called subsequent blocking occurs when the foil is stacked under the influence of heat or pressure. This has a negative impact on the subsequent processes following the

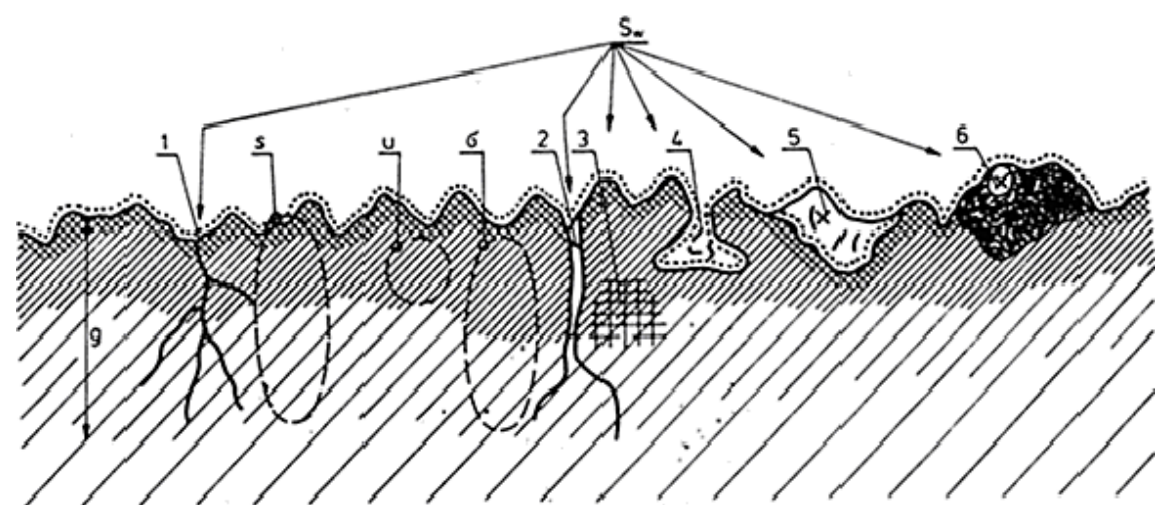

Fig. 3. Imperfections occurring in the surface layer, where: $g$ - thickness of the layer; $\mathrm{s}$ - structure of the surface layer; $\mathrm{u}$ - solidification; $\sigma$ - own strains of the surface layer; $\mathrm{S}_{\mathrm{w}}$ - contamination of the surface layer; 1 microcracks; 2 - crevince; 3 - shrinkage porosity; 4 - pore; 5 - chuckhole; 6 - inclusions 
foil production, such as printing. It can be noticed that low molecular weight fractions (or wax supplements) produce an adhesive layer on the surface of the foil. In this case, the force that is needed to separate the two layers of foil is called the anti-blocking force. Foils with a very smooth surface are more susceptible to the phenomenon of blocking, as this increases the adhesion between the foil layers and the value of the coefficient of friction. Anti-blocking agents are very often added to the material formulas used in the production of foil to prevent blocking the foil with another foil or sticking the foil successive layers together in the packaging process at high speed and during the storage of already finished products. Antiblocking additives first of all minimize adhesion and, thus, reduce the blocking force between the foil layers. When the correct anti-blocking agent is applied, the handling of the foil is much easier. The anti-blocking agents improve the mechanical tooling properties of the material i.e. minimizing blocking factor of the foil against another one and the reduced friction coefficient of friction the final laminate. An example of a product with and without the supplement is shown in Figure 4.

Many functional features of plastic products are related to processes and phenomena occurring on their surface. The basic supplements enabling the modification of the surface characteristic of materials are: antistatics, adhesion promoters, slip, non-slip, anti-blocking and anti-diving supplements.

In the case of foil production, slip, anti-slip, anti-blocking and anti-hunting supplements find frequent application. Lubricants are added when the foils (e.g. in the form of a sleeve) exhibit too high tendency of adhering to each other or to mechanical parts, which makes it difficult, and often
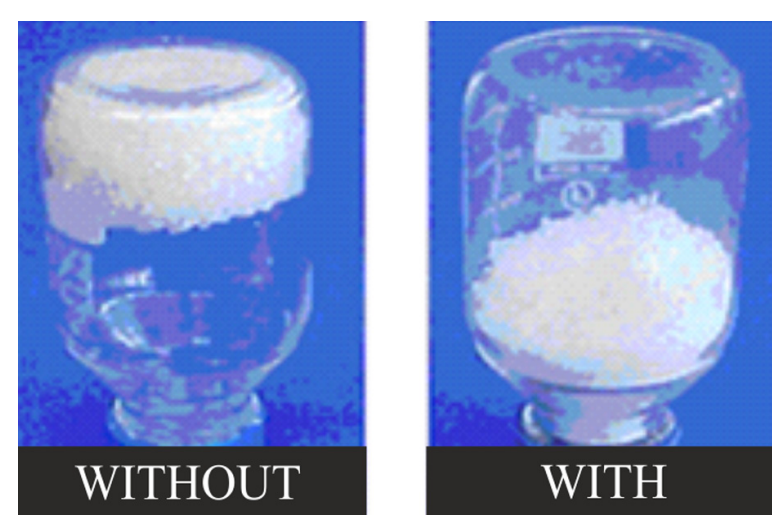

Fig. 4. Display of anti-blocker Ceridust 6050M: without / with the supplement impossible, to separate them (e.g., opening the pouch). This particularly applies to polyethylene (LD-PE, HD-PE) and polypropylene (PP) foils. Highly effective lubricants for polyethylene and polypropylene are respectively oleamide and erucamide added in an amount of about $0.05 \%$ to the polymer. The most efficient anti-blocking agents, added to the polymer mass in the amount of approx. $0.1 \%$, include finely shredded chalk and silica. As far as chlorinated plastics (PVC) are concerned, amide wax in the amount of approx. $1 \%$ is also applied $[2,14,18]$.

\section{RESEARCH METHODOLOGY}

The purpose of the research is to determine the static friction force $F_{s}$ and kinetic force $F_{k}$, as well as the friction coefficients corresponding to these forces: $\mu_{\mathrm{s}}, \mu_{\mathrm{k}}$. The research was carried out on the samples of foil in a form of a sleeve, obtained as a result of extrusion with blowing (temperatures in particular zones) respectively 185, 195, 200, 210 centigrade and $300 \mathrm{~mm}$ wide. Seven types of foil made of LDPE Malen E, MFR about 2 g / 10 min were used for the tests, of which samples $A$ and $G$ were made of foil without auxiliary supplements, and samples B, C, D, E, F contained supplements in the form of chemical compounds such as: erucic acid amide $\left(\mathrm{C}_{22} \mathrm{H}_{42} \mathrm{O}_{2}\right)$, behenic acid amide $\left(\mathrm{C}_{21} \mathrm{H}_{43} \mathrm{COOH}\right)$, colloidal silica, potassium soap or talc. All substances added to the foil were initially introduced into the concentrate on a twin screw extruder $2 \times 18 \mathrm{~L} / \mathrm{D}=25$ and then added to the material during the foil extrusion.

- Sample B contained supplements: erucic acid amide $(0.06 \%)$, behenic acid amide $(0.06 \%)$ and talc $(0.1 \%)$.

- Sample C contained supplements: erucic acid amide $(0.12 \%)$, potassium soap $(0.05 \%)$ and colloidal silica $(0.08 \%)$.

- Sample D contained supplements: erucic acid amide $(0.04 \%)$, behenic acid amide $(0.08 \%)$ and colloidal silica $(0.15 \%)$.

- Sample E and F contained a supplement in the form of erucic acid amide in the amounts of $0.05 \%$ and $0.1 \%$ respectively.

\section{Research position}

The tests were carried out on a friction test stand that ensures the moving of the measuring carriage with a given mass $G_{1}, G_{2}$, with a con- 
stant linear velocity V. During the measurement, the trolley with a stretched foil section was connected with a foil section placed on a flat measuring table. During the movement of the trolley, the force was measured parallel to the direction of its movement by means of the ZAD-1 Imada digital dynamometer with the maximum force recording range up to $20 \mathrm{~N}$ (Fig. 5.).

\section{Experimental procedure}

The foils used in each case were associated with each other on the inner surface. The measurements were carried out in the range of velocity possible to obtain on a special test stand, which the Polymer Processes Department is equipped with. The following testing conditions were adopted:

- dimensions of the $80 \times 80 \mathrm{~mm}$ measuring carriage;

- foil pressure force $\mathrm{G}_{1}=28.46 \mathrm{~N}, \mathrm{G}_{2}=38.27 \mathrm{~N}$;

- trolley travel speed $\mathrm{V}=13 \mathrm{~mm} / \mathrm{min}$.

On the basis of the obtained diagrams of dependences of friction force changes during the test, $F_{S}$ and $F_{K}$ were determined for which the values of friction coefficients sought were calculated (1).

$$
\mu_{s}=\frac{F_{s}}{G_{1,2}} \quad \mu_{K}=\frac{F_{k}}{G_{1,2}}
$$

\section{RESULTS AND DISCUSSION}

The results of the measurements are summarized in Tables 1-8. Additionally, the collected

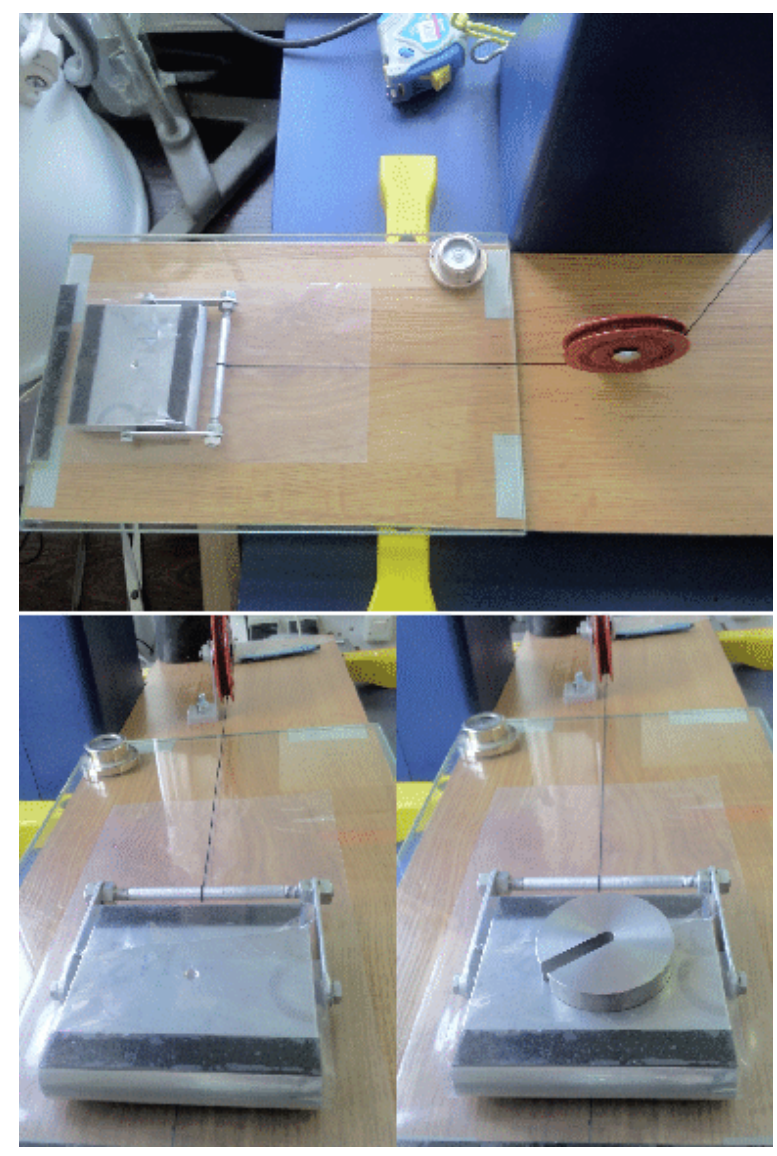

Fig. 5. The view of the measuring stand, Measuring cart with a load $\mathrm{G}_{1}=28.46 \mathrm{~N}$ and $\mathrm{G}_{2}=38.27 \mathrm{~N}$

results are shown graphically in Figure 6 (for $\mathrm{G}_{1}$ load) and Figure 7 (for $\mathrm{G}_{2}$ load).

The research results show that the use of erucic acid and behenic acid supplements have an effect on reducing the friction coefficient of the foil. Additionally, the use of colloidal silica has a posi-

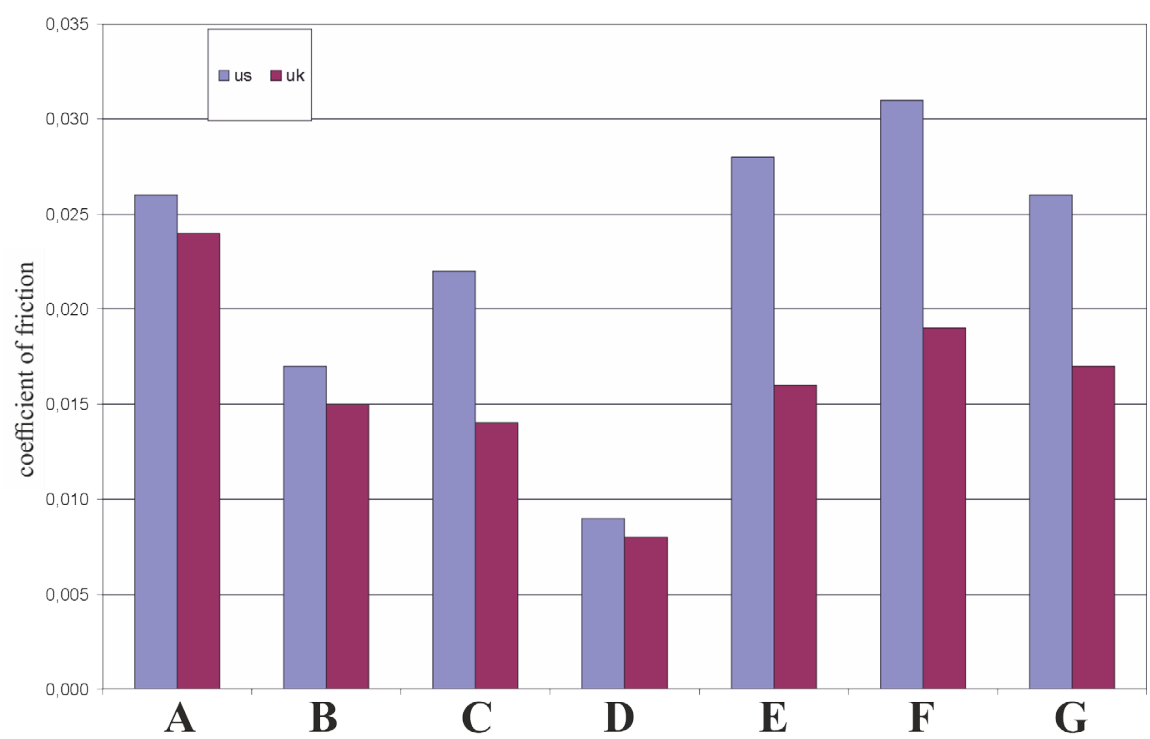

Fig. 6. Graph of the coefficient of friction for individual samples under pressure $G_{1}$ 


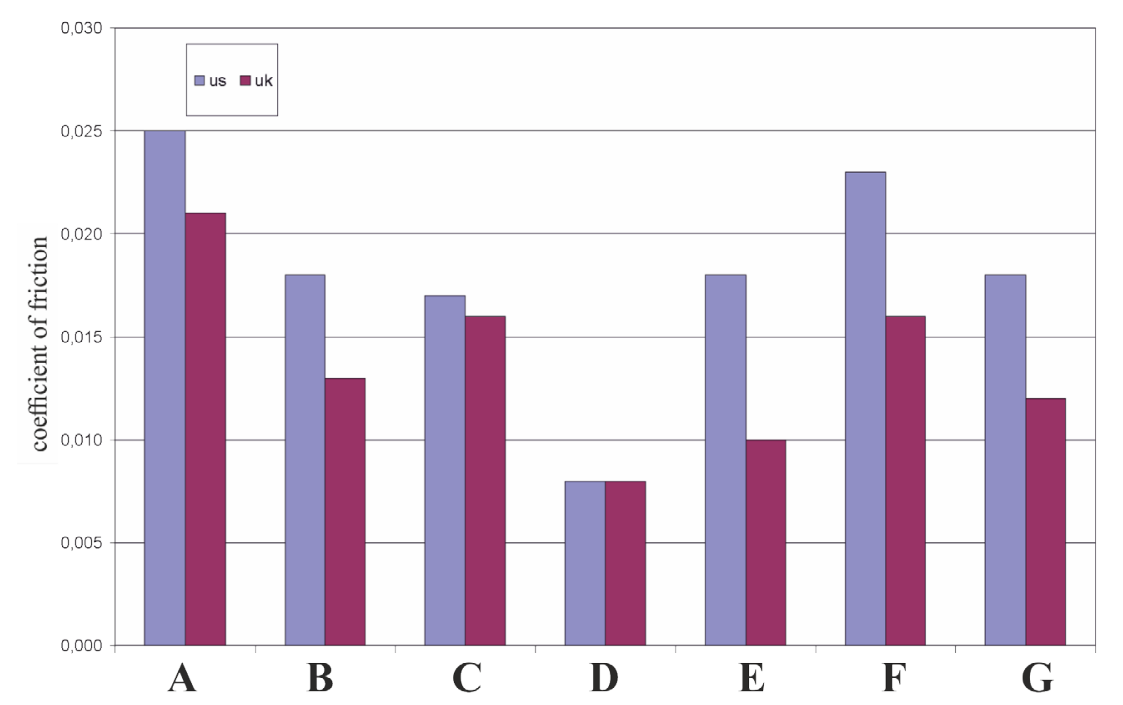

Fig. 7. Graph of the coefficient of friction for individual samples under pressure $\mathrm{G}_{2}$

Table 1. Measurement results for sample A

\begin{tabular}{|c|c|c|c|c|}
\hline \multirow{2}{*}{ Foil sample } & \multicolumn{2}{|c|}{$\mathrm{G}_{1}$} & \multicolumn{2}{c|}{$\mathrm{G}_{2}$} \\
\cline { 2 - 5 } & $\mathrm{F}_{\mathrm{S}}$ & $\mathrm{F}_{\mathrm{K}}$ & $\mathrm{F}_{\mathrm{S}}$ & $\mathrm{F}_{\mathrm{K}}$ \\
\hline \multirow{3}{*}{$\mathrm{A}$} & 0.72 & 0.67 & 0.84 & 0.76 \\
\cline { 2 - 5 } & 0.80 & 0.68 & 1.00 & 0.84 \\
\cline { 2 - 5 } & 0.69 & 0.74 & 0.98 & 0.82 \\
\hline \multirow{3}{*}{$\begin{array}{c}\text { Average } \\
\text { factor }\end{array}$} & 0.74 & 0.70 & 0.94 & 0.81 \\
\cline { 2 - 5 } & $\mu_{\mathrm{s}}$ & $\mu_{\mathrm{k}}$ & $\mu_{\mathrm{s}}$ & $\mu_{\mathrm{k}}$ \\
\cline { 2 - 5 } & 0.026 & 0.024 & 0.025 & 0.021 \\
\hline
\end{tabular}

Table 2. Measurement results for sample B

\begin{tabular}{|c|c|c|c|c|}
\hline \multirow{2}{*}{ Foil sample } & \multicolumn{2}{|c|}{$\mathrm{G}_{1}$} & \multicolumn{2}{c|}{$\mathrm{G}_{2}$} \\
\cline { 2 - 5 } & $\mathrm{F}_{\mathrm{S}}$ & $\mathrm{F}_{\mathrm{K}}$ & $\mathrm{F}_{\mathrm{S}}$ & $\mathrm{F}_{\mathrm{K}}$ \\
\hline \multirow{3}{*}{$\mathrm{B}$} & 0.5 & 0.434 & 0.72 & 0.653 \\
\cline { 2 - 5 } & 0.45 & 0.39 & 0.67 & 0.425 \\
\cline { 2 - 5 } & 0.47 & 0.44 & 0.69 & 0.459 \\
\hline \multirow{3}{*}{$\begin{array}{c}\text { Average } \\
\text { factor }\end{array}$} & 0.473 & 0.421 & 0.693 & 0.512 \\
\cline { 2 - 5 } & $\mu_{\mathrm{s}}$ & $\mu_{\mathrm{k}}$ & $\mu_{\mathrm{s}}$ & $\mu_{\mathrm{k}}$ \\
\cline { 2 - 6 } & 0.017 & 0.015 & 0.018 & 0.013 \\
\hline
\end{tabular}

Table 3. Measurement results for sample C

\begin{tabular}{|c|c|c|c|c|}
\hline \multirow{2}{*}{ Foil sample } & \multicolumn{2}{|c|}{$\mathrm{G}_{1}$} & \multicolumn{2}{c|}{$\mathrm{G}_{2}$} \\
\cline { 2 - 5 } & $\mathrm{F}_{\mathrm{S}}$ & $\mathrm{F}_{\mathrm{K}}$ & $\mathrm{F}_{\mathrm{S}}$ & $\mathrm{F}_{\mathrm{K}}$ \\
\hline \multirow{3}{*}{$\mathrm{C}$} & 0.54 & 0.4 & 0.65 & 0.57 \\
\cline { 2 - 5 } & 0.74 & 0.42 & 0.64 & 0.629 \\
\cline { 2 - 5 } & 0.63 & 0.4 & 0.64 & 0.63 \\
\hline \multirow{3}{*}{$\begin{array}{c}\text { Average } \\
\text { factor }\end{array}$} & 0.637 & 0.407 & 0.643 & 0.610 \\
\cline { 2 - 5 } & $\mu_{\mathrm{s}}$ & $\mu_{\mathrm{k}}$ & $\mu_{\mathrm{s}}$ & $\mu_{\mathrm{k}}$ \\
\cline { 2 - 5 } & 0.022 & 0.014 & 0.017 & 0.016 \\
\hline
\end{tabular}

Table 4. Measurement results for sample D

\begin{tabular}{|c|c|c|c|c|}
\hline \multirow{2}{*}{ Foil sample } & \multicolumn{2}{|c|}{$\mathrm{G}_{1}$} & \multicolumn{2}{c|}{$\mathrm{G}_{2}$} \\
\cline { 2 - 5 } & $\mathrm{F}_{\mathrm{S}}$ & $\mathrm{F}_{\mathrm{K}}$ & $\mathrm{F}_{\mathrm{S}}$ & $\mathrm{F}_{\mathrm{K}}$ \\
\hline \multirow{3}{*}{$\mathrm{D}$} & 0.26 & 0.226 & 0.33 & 0.28 \\
\cline { 2 - 5 } & 0.25 & 0.24 & 0.32 & 0.29 \\
\cline { 2 - 5 } & 0.27 & 0.25 & 0.31 & 0.3 \\
\hline \multirow{3}{*}{$\begin{array}{c}\text { Average } \\
\text { factor }\end{array}$} & 0.260 & 0.239 & 0.320 & 0.290 \\
\cline { 2 - 5 } & $\mu_{\mathrm{s}}$ & $\mu_{\mathrm{k}}$ & $\mu_{\mathrm{s}}$ & $\mu_{\mathrm{k}}$ \\
\cline { 2 - 5 } & 0.009 & 0.008 & 0.008 & 0.008 \\
\hline
\end{tabular}

Table 5. Measurement results for sample E

\begin{tabular}{|c|c|c|c|c|}
\hline \multirow{2}{*}{ Foil sample } & \multicolumn{2}{|c|}{$\mathrm{G}_{1}$} & \multicolumn{2}{c|}{$\mathrm{G}_{2}$} \\
\cline { 2 - 5 } & $\mathrm{F}_{\mathrm{S}}$ & $\mathrm{F}_{\mathrm{K}}$ & $\mathrm{F}_{\mathrm{S}}$ & $\mathrm{F}_{\mathrm{K}}$ \\
\hline \multirow{3}{*}{$\mathrm{E}$} & 0.7 & 0.386 & 0.66 & 0.35 \\
\cline { 2 - 5 } & 0.86 & 0.519 & 0.75 & 0.454 \\
\cline { 2 - 5 } & 0.79 & 0.45 & 0.68 & 0.39 \\
\hline \multirow{3}{*}{$\begin{array}{c}\text { Average } \\
\text { factor }\end{array}$} & 0.783 & 0.452 & 0.697 & 0.398 \\
\cline { 2 - 5 } & $\mu_{\mathrm{s}}$ & $\mu_{\mathrm{k}}$ & $\mu_{\mathrm{s}}$ & $\mu_{\mathrm{k}}$ \\
\cline { 2 - 5 } & 0.028 & 0.016 & 0.018 & 0.010 \\
\hline
\end{tabular}

Table 6. Measurement results for sample F

\begin{tabular}{|c|c|c|c|c|}
\hline \multirow{2}{*}{ Foil sample } & \multicolumn{2}{|c|}{$\mathrm{G}_{1}$} & \multicolumn{2}{c|}{$\mathrm{G}_{2}$} \\
\cline { 2 - 5 } & $\mathrm{F}_{\mathrm{S}}$ & $\mathrm{F}_{\mathrm{K}}$ & $\mathrm{F}_{\mathrm{s}}$ & $\mathrm{F}_{\mathrm{K}}$ \\
\hline \multirow{4}{*}{$\mathrm{F}$} & 0.81 & 0.54 & 0.85 & 0.58 \\
\cline { 2 - 5 } & 0.94 & 0.56 & 0.92 & 0.68 \\
\cline { 2 - 5 } & 0.86 & 0.55 & 0.87 & 0.6 \\
\hline \multirow{3}{*}{$\begin{array}{c}\text { Average } \\
\text { factor }\end{array}$} & 0.870 & 0.550 & 0.880 & 0.620 \\
\cline { 2 - 5 } & $\mu_{\mathrm{s}}$ & $\mu_{\mathrm{k}}$ & $\mu_{\mathrm{s}}$ & $\mu_{\mathrm{k}}$ \\
\cline { 2 - 5 } & 0.031 & 0.019 & 0.023 & 0.016 \\
\hline
\end{tabular}




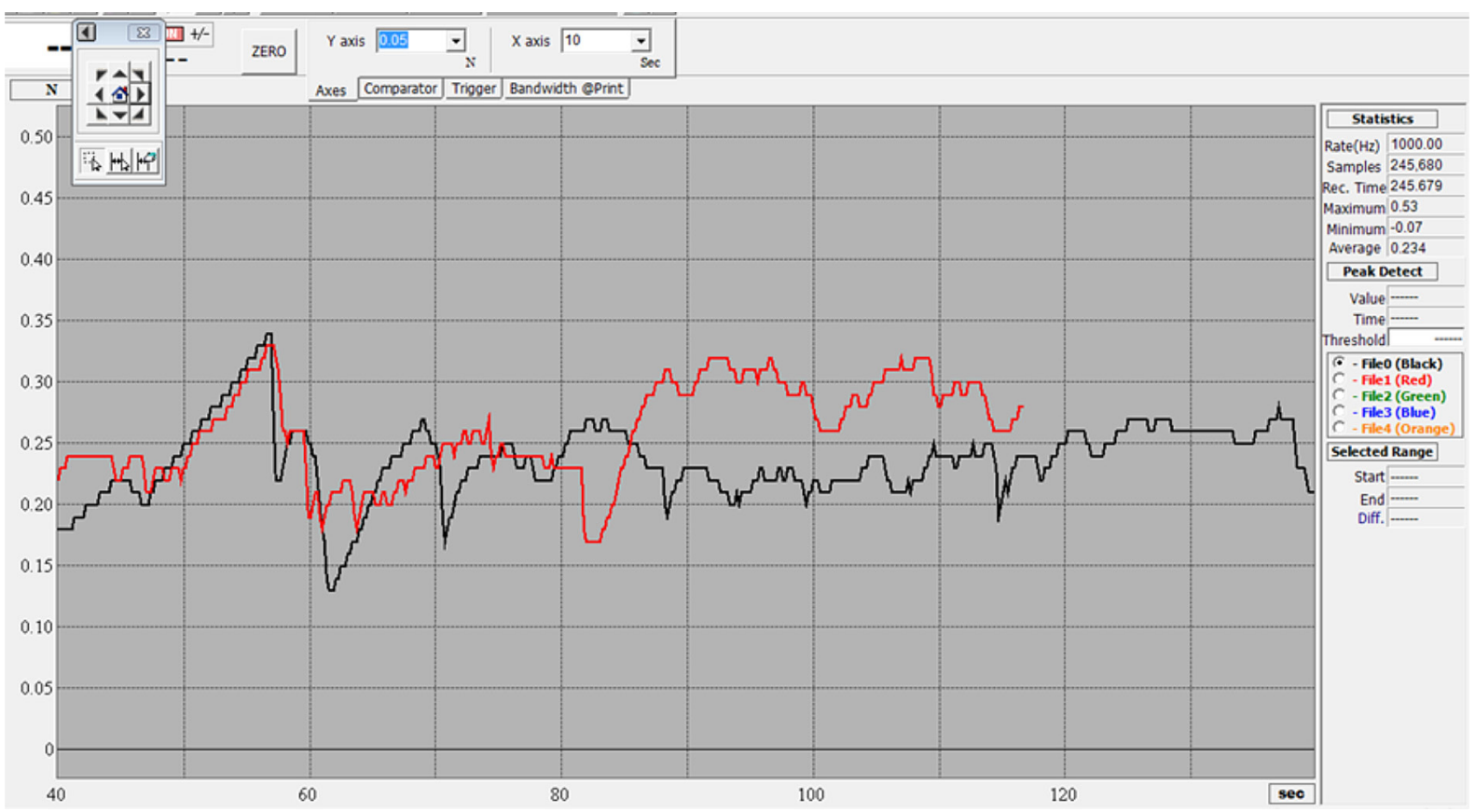

Fig. 8. Diagram of friction measurement of sample D.

Table 7. Measurement results for sample $G$

\begin{tabular}{|c|c|c|c|c|}
\hline \multirow{2}{*}{ Foil sample } & \multicolumn{2}{|c|}{$\mathrm{G}_{1}$} & \multicolumn{2}{c|}{$\mathrm{G}_{2}$} \\
\cline { 2 - 5 } & $\mathrm{F}_{\mathrm{s}}$ & $\mathrm{F}_{\mathrm{K}}$ & $\mathrm{F}_{\mathrm{s}}$ & $\mathrm{F}_{\mathrm{K}}$ \\
\hline \multirow{3}{*}{$\mathrm{G}$} & 0.62 & 0.46 & 0.57 & 0.41 \\
\cline { 2 - 5 } & 0.77 & 0.49 & 0.68 & 0.49 \\
\cline { 2 - 5 } & 0.86 & 0.46 & 0.78 & 0.5 \\
\hline \multirow{3}{*}{$\begin{array}{c}\text { Average } \\
\text { factor }\end{array}$} & 0.750 & 0.470 & 0.677 & 0.467 \\
\cline { 2 - 5 } & $\mu_{\mathrm{s}}$ & $\mu_{\mathrm{k}}$ & $\mu_{\mathrm{s}}$ & $\mu_{\mathrm{k}}$ \\
\cline { 2 - 5 } & 0.026 & 0.017 & 0.018 & 0.012 \\
\hline
\end{tabular}

tive effect on the aforementioned property. The use of talc or potassium soaps does not influence the reduction of the sliding coefficient of friction.

The best results, as friction minimizing supplements, showed sample $\mathrm{D}$, containing erucic acid, behenic acid and colloidal silica. Figure 8 is a graph of the friction test of sample D.

\section{CONCLUSIONS}

In the light of the presented research, applying supplements that improve the properties of polymer products is highly recommended as well as conducting research on the use of new modifiers.

Currently, new kinds of polyethylenes are produced to obtain more functional foils. Unfortunately, this carries a risk, especially in relation to products having direct contact with food, because of the possibility of getting the chemicals contained in the foil into a wrapped item. Therefore, it is worth conducting research, not only on the agents that improve the properties of the foil, but also on those that will be safe for the environment and health.

\section{REFERENCES}

1. Adelhafidi A., Babaghayou I., Chabira S., Sebaa M.: Impact of Solar Radiation Effects on the Physicochemical Properties of Polyethylene (PE) Plastic Film. Procedia - Social and Behavioral Sciences, Vol. 195, 2015, 2210-2217.

2. Butler T., Morris B.: 17: PE-Based Multilayer Film Structures. Multilayer Flexible Packaging (Second Edition), 2016, 281-310.

3. Coles R., Mcdowell D., Kirwan M.J., Food Packaging Technology, Blackwell Publishing CRC Press, 2003.

4. Gibas E. Folie polietylenowe - surowce i niezbędne dodatki, Przetwórstwo Tworzyw 3, 2014.

5. Jurkowska B., Jurkowski B., Sporządzanie kompozycji polimerowych, Warszawa, WNT 1995.

6. Klepka T.: Effectiveness of forming of polymeric special sliding layers. Polimery, vol.47, 9, 2002, 649-653.

7. Klepka T, Jeziórska R., Szadkowska A. Thin wall products made of modified high density polyethylene. Przemysl Chemiczny, Vol. 94, 8, 2015, 1352-1355. 
8. Ren C., Wang K., Nie Q., Wang D., Guo S.: Surface modification of PE film by DBD plasma in air., Applied Surface Science, Vol. 255, 5, Part 2, 2008, 3421-3425.

9. Ressel J., Seewald O., Bremser W., Richer H., Strube O.: Low friction poly(amide-imide) coatings with silicones as tethered liquids., Progress in Organic Coatings, Vol. 124, 2018, 1-7.

10. Rydzkowska T.: Properties of recycled polymer mixtures obtained in the screw-disc extrusion process. Polimery, vol. 56, 2, 2011, 135-139.

11. Saechtling H.: Tworzywa sztuczne Poradnik, WNT, 2000.

12. Samujło B., Charakterystyka procesu wytłaczania polietylenu modyfikowanego antypirenami bezhalogenowymi i środkami pomocniczymi, Polimery, vol. 48, 2003, p. 540.

13. Sasimowski E. Przetwórstwo tworzyw polimerowych : aspekty technologiczne i nowe trendy : część 1, Politechnika Lubelska, 2015.
14. Sasimowski E., Sikora J., Królikowski B.:Effectiveness of polyethylene extrusion in a single-screw grooved feed extruder. Polimery, 6, vol. 59 ,2004, 505-510.

15. Stasiek J., „Współczesne technologie i urządzenia do wytłaczania folii metodą wytłaczania $\mathrm{z}$ rozdmuchiwaniem. Cz. I. Wytłaczanie z rozdmuchiwaniem folii z tworzyw polimerowych", Polimery, vol. 50, 2005, p. 229.

16. Stepek, J., Daoust H., Additives for Plastics, Springer, New York, 1983.

17. Szlezynger W.: Tworzywa sztuczne, Wydawnictwo Oświatowe FOSZE, Rzeszów 1998.

18. Wróblewska-Krepsztul J., Rydzkowski T., Borowski G., Szczypiński M. , Klepka T., Thakur V. K.: Recent progress in biodegradable polymers and nanocomposite-based packaging materials for sustainable environment. International Journal of Polymer Analysis And Characterization, vol. 23, 4, 2018, 383-395. 